\title{
Richard's Physical Deformity, the Cause or Excuse behind His Wickedness: A Critical Analysis of Shakespeare's Richard III
}

\author{
Samina Akhtar ${ }^{1}$, Muhammad Rauf ${ }^{2}$, Saima Ikram $^{3}$ \& Seema Rehman ${ }^{4}$ \\ ${ }^{1}$ Deptartment of English, Govt. Girls Degree College Gulshan Rehman, Peshawar, Pakistan \\ ${ }^{2}$ Deptartment of Social Sciences and Humanities, CECOS University, Peshawar, Pakistan \\ ${ }^{3}$ Deptartment of English, Qurtuba Univeristy of Science and Information Technology, Peshawar, Pakistan \\ ${ }^{4}$ Deptartment of English, Shaheed Benazir Bhutto Women University, Peshawar, Pakistan \\ Correspondence: Samina Akhtar, Deptartment of English, Govt. Girls Degree College Gulshan Rehman, \\ Peshawar, Pakistan. E-mail: meenaiftikhar@yahoo.com
}

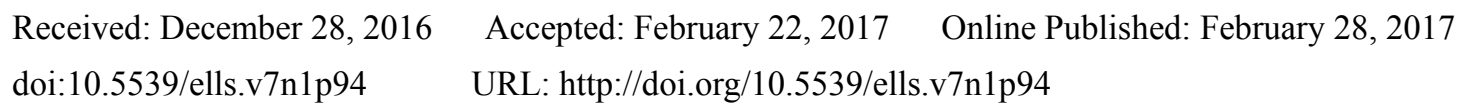

\begin{abstract}
This study is an attempt to explore the intrinsic behavior of Richard, the tragic hero of Shakespeare's renowned historical play Richard III. This paper interprets deformity is a cause or excuse behind Richard's wickedness that leads him towards his appalling disaster. It further evaluates the internal conflicts of Richard's mind, his lust for the throne and riches, and his ferocity to attain his lustful desires. The paper investigates whether Richard used his physical malformation as a defending tool or it is mere hindrance in his goodness. It also throws light on how Richard defends his wicked nature by blaming his deformity. The researcher critically studies the psyche of the genius but evil character through social and psychological perspective. The finding of the paper suggests that deformity reflects Richard's inward nature full of evil and vices and turns to be the real cause behind his abysmal calamity. Richard's malicious disability is the clear example of his inward evil.
\end{abstract}

Keywords: Richard III, physical deformity, inherent evil, society, calamity

\section{Introduction}

Richard III is widely conferred as a character of warped humanity, and this historical figure involved various scholars to extensive discussions about the obvious interconnection between his physical deformity and inherent evil. He has always been disapproved as the "arch-defective in all literature" and the principal illustration of "malevolent disability" (Snyder, 2005, p. 272).

Richard, the duke of Gloucester, who is described in the play as a deformed hunchback, fiendish, and a great manipulative murderer who mercilessly deceit and willing to dispose off any man, woman, or child who stands between him and the throne of England. In the play the distorted body of the tyrant ruler, Richard is always been at stake. He reveals himself as "cheated of feature" which associate insult to an anomalous body.

This study aims to analyze the inherent evil in the deformed body and evaluates the internal conflicts going on in the mind of Richard. It discussed and answered the questions flit around one's mind regarding Richard's malevolent disability. My analysis explores Richard as a deformed character, a wicked son and brother and a tyrant ruler who blamed his deformity for his wickedness and considered it as an impediment in his good nature. He does not realize the immoral and depraved ways that he has adopted to attain the throne. In other words, he used physical deformity as an excuse for his wickedness and autocracy.

In the opening scene of the play, Richard III, Richard tells the readers in his speech that he was born "deformed", "unfinished" and was "sent before [his] time into this breathing world, scarce half made-up" (1. 1.1)

Throughout the play, the characters discuss Richard's body in a number of ways: Anne and Elizabeth describe him as "lump of foul deformity", "diffused infection of a man", "hedgehog", "bottled spider" and "poisonous bunch-backed toad", "Slander of thy mother's heavy womb". All these insulting terms are very offensive and hateful for Richard.

In a profoundly religious sense at that time, physical deformity was certainly considered as the work of God. Even different people might react with resentment at their disability. However, the more likely consequence would be a 
"hair shirt" approach towards physical malformation and it is considered as a burden to be endured with self-effacement. Richard being a religious man appears to have taken the second way. However the people around Richard might think his physical deformity as an emblem of evil.

Richard is treated very inhumanely in his family and social circle. Such a cruel behavior towards a physically deformed person crop up a question in one's mind, whether Richard is evil by nature? Or it is the attitude of the people towards his deformity that made him wicked? Critics also raise different questions while discussing Richard's deformities, and wondering whether they are the tangible manifestations of an inner evil or they themselves are the root of his wickedness. Shakespeare's treatment of Richard, Duke of Gloucester's physical deformity is often used by literary scholars as a point of departure for the asking of some fundamental metaphysical questions: Is his deformity a sign of his innate inward corruption, or is it the cause of his iniquity? It is evidently clear that deformity must in some way be directly linked to his absent morality.

\section{Critical Analysis of the Play}

The one thing that everybody knows about Richard III is that he is deformed, "misshapen" (Note 1), a hunchback with a withered arm. His outward appearance, in its blatant violation of "fair proportion" (Richard III, i.i.18), reflects his inward nature.

Then, since the heavens have shaped my body so,

Let hell make crook'd my mind to answer it.

(3Henry VI, 56, pp. 78-79)

Richard is "determined to prove a villain" in more ways than one: he has chosen to be a villain by a conscious exercise of his will, like Milton's Satan (Note 2) in proclaiming "Evil be thou my good", or, alternatively, he has been acted on, pushed in a fastidious direction, by deterring forces not under control. Richard vans his distorted body in ways that precede his political command. Appealing to physical deficiency and the inability he claims serve to vague his clever political maneuvers. Marjorie Garber (Note 3) utters: "Richard's deformed body is a mirror for the self-confessed ugliness" (p. 81)

Richard's enticing character is compelling to readers, actors and especially to critics. Scholars such as Marry Anne and McGrail have attempted to determine how Richard's wickedness functions as a response to his own deformed body and to the world in which he lives.McGrail asserts that Richard's decision to play the usurper and tyrant is a direct result of his resentment of nature's distortion of his body, and argues that Richard's conviction that no one can love his deformed body is what drives him to seek vengeance against his world and the people in it.

The opening soliloquy of the play reflects Richard's thoughts about his warped body:

I that am curtailed of this fair proportion,

Cheated of feature by dissembling nature,

Deformed, unfinished, sent before my time

Into this breathing world scarce half made up-

And therefore since I cannot prove a lover

To entertain these fair well-spoken days,

I am determined to prove a villain

And hate the idle pleasures of these days.

(1.i. pp. 18-31)

Richard's use of the words "deformed" and "unfinished", along with his admission that he is "scarce half made up", emphasize the fact that Richard perceives himself as lacking in some significant way, that he is a flawed man, as Lady Anne points out, Richard is a "diffused infection of a man" (1.ii. p. 78).

Richard's deformity, breaking through his many masks, can appear to other characters as a clear sign of the hideous and unnatural. In the tetralogy as a whole, Richard's deformed body is symbolic of a disordered world, torn apart by civil war and the unleashing of the will to destruction. To Richard himself an awareness of deformity provides an urge to action, an impulsion for revenge on the "dissembling nature" which has mocked and cheated him. 
In the terms of Frances Bacon's Essay "Of Deformity", deformity is not so much a "sign" as it is a "cause". Warren Chernaik argues that physically deformed and warped individuals are usually even with nature, for as nature has done wrong by them, so do they by nature. He further states that if somebody has something fixed in his personality that provoked hatred and contempt, has also an everlasting spur to save and set free himself from contempt. Also, it becomes their habit to observe and search for the weakness of others, that they may have somewhat to pay back. Chernaik considers deformity is an advantage to rising. (Note 4)

In his soliloquy at the beginning of the play Richard presents himself precisely in this way, as provoked and aggravated by burning desires to triumph over his bodily disadvantages, thus arming himself against any expected derision in the merciless gaze of others. Richard laments over his physical attributes which are shown here to be that of a deformed monster, unattractive to women and so badly made that even dogs bark at him as he passed by them. Richard cries:

"I that am curtailed of this fair proportion,

And that so lamely and unfashionable

That dogs bark at me as I halt by them."

(1.i.1 pp. 8, 22, 23)

Indecisive of the literal reason of his physical accountability, Richard takes revenge upon a world that emanate him as "unfit" and a family that consider of him as a "curse". Mitchell and Sharon argue that Like Bladerunner's cyborgs, Richard III seems to seek recompense for fixed-in "defects"- the problem is that his "vengeance" devise numerous and uneven targets of retribution. Richard finds little in the way of salvation for his deformed body, he tosses in his lot with the distorted and blemished authority of demonic nature. The only critical belief has been that in Richard's own "distorted" body he finds an avocation. (Note 5)

In the article "A monster Great Deformed: The Unruly Masculinity of Richard III", Ian Frederick Moulton elucidates that Shakespeare used Richard to symbolize the utmost masculine being. In a time when England was being ruled by a female, the roles of gender appeared to be imprecise and various men were adopting the roles of women. Richard's character is a reaction to this phenomenon, Shakespeare twisted a character that was to epitomize all things masculine and resist all things feminine. This makes Richard's egotistic schemes and also his deformed body explicated by his overstated masculine image. Moulton further asserts as to why his deformity is designed masculine, "In the absence of strong masculine royal authority, English manhood, unruled and untamed, turns to devour itself. It is this unregulated, destructive masculine force that is personified in the twisted and deformed body of Richard III" (Moulton, p. 258).

At different places, by amplifying; even parodyinghis deformity, Richard shows his determination to defeat it. Sheridan Morley (2003) remarks in his article that Richard III inquires if the king is innately wicked, or just the clever but twisted product of a detested and unloving family.

Trotter (1993) asserts that an important theme of Richard III is Richard's disgust with the world of flesh and his efforts to surmount the inadequacies of nature, particularly as they are exposed by his own body. Trotter sees strong evidence of this theme in Act I in Richard's courtship of Lady Anne. The critic proposes that Richard's disrespect and hatred for Lady Anne, once he effortlessly persuaded her to be his wife, is not simply asign of his hatred of women, but more significantly is a symbol of his distaste with the flesh in general. Richard declares that his "lameness" is the reason why no woman ever wants to love or marry him, which is why he "determined" to be a "villain". Similarly, Plasse (1995) argues that Richard uses his malformed body as an excuse to behave viciously. In other words, Plasse elucidates, Richard feels that he is ensnared in a twisted body and is therefore, preferably shaped for bitter acts, such as punishing or murdering his enemies.

Richard physical deformity is frequently cited as an indication of Richard's moral deformity. For whatever reason, Richard's morality is not only missing a little - it's just not present. Since Richard doesn't raise a question about his morality. We don't have to ask either. When Richard does have one petrified moment of questioning himself, he comes to the fact that "I am myself alone".

Richard is a villain, fine, but what does this really mean, and why? We might think Richard a victim of circumstance. He is physically deformed, far from the throne, and his family hates him. Of course he is messed up. It might be the lack of love and attention from the family that turns him towards wickedness. It might be the curses of his mother and Anne, his future wife that provoked him to act like devil. The duchess deprives him from the love of a mother when she says about him, 
“Thou elvish-mark'd, abortive, rooting hog

Thou what mustsealed in the nativity

The slave of Nature, and son of hell;

(1.3. pp. 228-230)

This can be symbol of the whole society, which mock him and consider him not to be able for achieving. Who says Richard can't achieve? He shows his powers and his intelligence to achieve from what he is deprived. From a psychological point of view a person compensate psychologically for his physical disability.

Richard has never experienced love and has never been loved by anyone since his childhood. He was not loved by his mother and wife or any of the family member where else he should have learnt it? Richard was a premature baby and this may be the reason behind his deformity. Society cannot accept such people, so he was also not accepted by the society. Even his own mother despises him when she says:

"And I, for comfort, have but one false glass,

That grieves me when I see my shame in him."

(2.2. pp. 53-54)

Anne calls him a "hedgehog" (1.2. p. 104) and curses him to be damned. This was his only weakness which makes him unacceptable to society. In order to defend his weakness, he decided to take revenge on the society that is why he decided to be a "villain".

"Then since the heaven have shap'd my body

Let hell make crook'd my mind to answer it."

(3 Henry VI, v, 6, pp. 78-79)

Richard's deformity is the central question in the play. Does his deformity reflect his twisted morality or it is his twisted morality the cause of his deformity, a punishment from Nature? We have key to answer this unanswerable question in the first speech, when Richard says he is "determined to prove a villain". How we read this line influences how we interpret Richard's character. Richard might be determined in the sense of being committed to be a villain, or Richard might be determined or predestined in the sense of Calvinist predetermination. (Note 6)

Shakespeare based his character on historical accounts of the great philosopher Thomas More (Note 7). In his book The History of King Richard the Third (c. 1513); Thomas More approved Richard as a dictator whose physical deformity was just as twisted as his wicked nature. He portrayed Richard III as:

“ $\{\ldots\}$ little of statue, ill featured of limbs, crook backed, his left shoulder much higher than his right, hard favored of visage $\{\ldots\}$ he was malicious, wrathful, envious and from his birth ever forward.” p. 37a)

The question arises how can a child be malicious and wrathful? How can an innocent child be envious from his birth? Physically deformed children are more sensitive. They can realize attitude and behaviors more than normal people. Physically deformed children are also innocent and far from vices but they can realize the rejection on part of society as soon as in their childhood. So, they try to compensate psychologically for their physical disability. In psychological point of view there is enormous drive working behind their psyche. Francis Bacon in his essay Of Envy stated that:

"Deformed persons, and Eunuchs and Old Men, and Bastards, are Envious; for he that cannot possibly mend his own case, will do what he can to impair others". (p. 105)

Moulton depicts the way in which deformity was perceived in the sixteenth century as associated to eroticism, sin, female imagination during childbirth and was believed intimidating to the nation (p. 262-263). In Richard III, Shakespeare presented Richard more conscious and alert about his deformity. So, he started defending himself from the very beginning. He can't tolerate the mocking of the society and can't bear the hatred and disliking of his own family. He developed his own ways for surviving among the handsome. Being unloved he decided to snatch love by force. Richard has been suffered long for his deformity and he knew the pains of a deformed body. He was deprived of the love of a mother and family which led him towards his wicked behavior. His wickedness tends him to prepare a "to do list" for the future which is full of murders, wickedness at the peak and gained the name of "evil genius". It is his own decision to be an evil, so, from his body; deformity spreads over all his character. He himself says in the opening scene: 
"Why, I, in this weak piping time of peace,

Have no delight to pass away the time,

Unless to spy my shadow in the sun

And descant of mine own deformity;

And, therefore, since I cannot prove a lover,

To entertain these fair well-spoken days,

I am determined to prove a villain,

And hate the idle pleasure of these days."

It might be his physical deformity that made him a vengeful tyrannical man, who can plotted so well but unfortunately his genius is used all in evil not in God's ways. Carl Jung (Note 8) states in Archetypes and the Collective Unconscious:

"The shadow personifies everything the subject refuses to acknowledge about himself and yet is always thrusting itself upon him directly or indirectly." It simply means that any part of ourselves that we disown and reject split off and becomes more primitive and can be easily projected outward. We should accept this primitive and unpleasant part of ourselves in order to become a whole, else these negative attributes attack us from the outside and we projected it in others. To interpret Richard's wickedness in Jungian perspective i.e., being the work of his unconscious mind. It is the outburst of his darker and dense shadow which is covering the whole personality of Richard.

Richard could also be someone with a sound moral attitude, and he shows that he can also be gentle and kind. His gentleness and kindness towards the young prince prove him to be a gentleman. The young prince says:

"Grandam, we can: for my good uncle Gloucester

[....]

And when my uncle told me so he wept,

And pitied me, and kiss'd my cheek;

Bade me rely on him as on my father.

And he would love me dearly as a child".

(Richard III, 11.11)

Richard plays the devil, but he can prove to be a saint with such a genius mind. Literary critic Marjorie Garber in his critique "Descanting on Deformity: Richard III and The Shape of History" remarks that "Shakespeare's Richard III is arguably the first fully realized and psychologically conceived character in his plays. Like the god Proteus, who could change his shape at will, like the chameleon that changes its colors to conceal itself from view."

Marcella Kostihova argues that imitating on the possible correspondence between Richard's inwardness and the abhorrence he received from those around him, which in result compelled him to the horrifying actions he pledges in the play. (Note 9)

Richard has psychological motives. He tells us that he is aware of his physical deformities and feels insecure, inadequate, and isolated. He is a lot more complex than the flat, stock figure from the old morality plays. We may call Richard III the great grandfather of complex characters like Macbeth and Hamlet.

\section{Conclusion}

Richard failed to recognize his genius through which he can conquer the world without being the part of devil. He used deformity as an excuse to fulfill his lustful desires that brings his catastrophe at the end. Richard employs his emblematic power to recompense for a bodily form marked with despicable associations.

Shakespeare creates Richard with a degree of humanity. Because he cannot "prove a lover" and enjoy the time of peace due to his deformity, Richard decides that he will "prove a villain" and seek power for himself. In this way, Shakespeare gives Richard a motivation for his villainy. Richard is not the typical Medieval Vice (Note 10) characters. He may resemble a typical "Machiavellian" villain. (Note 11) Shakespeare presented Richard III as a complicated human being and reflection of him as such, rather than as an immoral and monstrous caricature, moves us relatively closer to comprehend the incentives behind his cruel acts by which history recalls him. 
Shakespeare portrays Richard is a believable character, not a personification of evil. Since childhood Richard has been mocked at which turned him to act like a "BOAR". (Note 12) Being suffered, he decided to take revenge on every one. Contemptuous behavior on part of nears and dears, hatred and rejection from society provoked, incited him to act like devil. Richard may be the ultimate arch-villain. He is also a credible, three-dimensional human being who, because of his deformity, lashes out at the world.

\section{References}

Chernaik, W. (2007). The Cambridge Introduction to Shakespeare's History Plays. Cambridge: Cambridge University Press.

Encyclopedia Britannica. (1999). Multimedia Edition: Adler, Alfred \& Fried.

Garber, M. (1988). Descanting on Deformity: Richard III and the Shape of Historyin: Dubrow, Heather Strier, Richard (Hg.): The Historical Renaissance. Chicago, London.

Jowell, J. (2000). William Shakespeare Richard III. Oxford: Oxford University Press.

Jung, C. (1996). The Archetypes and the Collective Unconscious. London.

Kostihova, M. (2016). Digging for perfection: Discourse of Deformity in Richard III's Excavation. Palgrave Communications, 2, 16046. https://doi.org/10.1057/palcomms.2016.61

Levine, N. (Ed.). (2011). Richard III: Evans Shakespeare.

Mitchell, D. T., \& Sharon, L. S. (2003). Narrative Prosthesis: Disability and the Dependencies of Discourse. Ann Arbor, Michigan: The University of Michigan Press.

More, T. (c.1513). The History of King Richard the Third. London.

Moulton, I. F. (1996). A Monster Great Deformed: The Unruly Masculinity of Richard III. Shakespeare Quarterly, 47(3), 251-268. Web. https://doi.org/10.2307/2871377

Plasse, M. A. (1995). Corporeality and the Opening of Richard III. In F. Robert (Ed.), Entering the Maze: Shakespeare's Art of Beginning. New York: Peter Lang.

Sara, H., \& Guerrin, N. (2005). Shakespeare on Screen: Richard III: Proceedings of the Conference.

Shakespeare, W., \& David, M. B. (1988). Richard III. Toronto: Bantam.

Snyder, S. (2005). Unfixing disability. In C. Sandahl \& P. Auslander (Eds.), Bodies in Comotion: Disability and Performance. Ann Arbor, MI: University of Michigan Press.

Torrey, M. (2000). The plain devil and dissembling looks': Ambivalent Physiognomy and Shakespeare's Richard III. English Literary Renaissance, 30(2), 123-153. https://doi.org/10.1111/j.1475-6757.2000.tb01167.x

Williams, S. K. (2009). Enabling Richard: The Rhetoric of Disability in Richard III. Disability Studies Quarterly, 29(4). https://doi.org/10.18061/dsq.v29i4.997

\section{Notes}

Note 1. Henry VI, 1(3). p. 170.

Note 2. Milton's Satan is one of the most dynamic and complicated characters in all of literature. He possesses an unhealthy thirst for vengeance and havoc like the little red dude with a pitchfork. Satan is flat-out, hands down, without a doubt, the best speaker in the poem. He's like the greatest Shakespearean actor. Sadly, however, Satan really is evil. But his is a very seductive kind of evil, which makes him even more dangerous.

Note 3. Marjorie B. Garber is a professor at Harvard University and the author of a wide variety of books, most notably ones about William Shakespeare and aspects of popular culture including sexuality.

Note 4. The Cambridge Introduction to Shakespeare's History Plays. p. 59

Note 5. For detail see, Mitchell, David T. and Sharon L. Snyder. Narrative Prosthesis: Disability and the Dependencies of Discourse. The University of Michigan Press. 2003. p. 100.

Note 6. John Calvin was the founder of Calvinism, a branch of Protestant Christianity. He believed that God determines everything that's going to happen to a person and whether he or she will be saved from damnation. This was a hot topic in Shakespeare's England.

Note 7. Sir Thomas More, known to Roman Catholics as Saint Thomas More since 1935, was an English lawyer, social philosopher, author, statesman, and noted Renaissance humanist. 
Note 8. Carl Gustav Jung was a famous Swiss psychotherapist and psychiatrist.He is the founder of analytical psychology. Jung anticipated and developed the conceptions of extroversion and the introversion psychological or personality. Carl Jung is known for his theory of archetypes, the collective unconscious and his studies of the human psyche.

Note 9. For details see Kostihova M. (2016). Digging for perfection: Discourse of Deformity in Richard III's Excavation

Note 10. Vice is a stock character of the medieval morality plays. While the main character of these plays was representative of every human being (and usually named Mankind, Everyman, or some other generalizing of humanity at large), the other characters were representatives of (and usually named after) personified virtues or vices who sought to win control of man's soul.

While the virtues in a morality play can be seen as messengers of God, the vices were viewed as messengers of the Devil.

Note 11. Machiavellian Villain is a character that is portrayed in literature as a puppet master who uses tool villains to get what his heart desires and always operates in secret, hiding his true intentions and thoughts from everyone. Machiavellian Villain is based on the philosophies of the Machiavelli, who wrote the prince.According to his popular and controversial theory, being a successful leader has nothing to do with being a nice person or doing the right thing. Instead, it's about being inventive, manipulative, charismatic, crafty, and willful).

Note 12. The Boar is Richard's heraldic mark, and is used several times throughout the play to represent him, most notably in Stanley's dream about Hastings's death. "The boar" is presented intentionally in the play in order to describe Richard's deformity. The duchess cursed Richard as an "abortive, rooting hog" (I.iii. p. 225). The people in the middle Ages and Renaissance used to hunt the Boar which was considered one of the most dangerous animals. The audience of Shakespeare also linked this fierce animal with wild aggression and irrepressible violence.

\section{Copyrights}

Copyright for this article is retained by the author(s), with first publication rights granted to the journal.

This is an open-access article distributed under the terms and conditions of the Creative Commons Attribution license (http://creativecommons.org/licenses/by/4.0/). 